\title{
Article
}

\section{Interest Rate in Pension Plan Premium Calculation}

\section{Article Info}

Article history :

Received April 14, 2020

Revised April 20, 2020

Accepted April 22, 2020

Published April 30, 2020

Keywords :

interest rate, pension, premium, FSL, PVFSAL, premiums, benefits

\section{Khafsah Joebaedi $^{* 1}$, Kankan Parmikanti ${ }^{1}$, Agus Supriatna ${ }^{1}$, Fauzi Akhmad $^{1}$, Badrulfalah ${ }^{1}$, Nendi Suhendi Syafei ${ }^{2}$}

${ }^{1}$ Department of Mathematics, Faculty of Mathematics and Natural Science, Universitas Padjadjaran, Bandung, Indonesia ${ }^{2}$ Department of Electrical Engineering, Faculty of Mathematics and Natural Science, Universitas Padjadjaran, Bandung1, Indonesia

\begin{abstract}
The defined benefit pension plan and premium payment (normal dues) are determined by life annuities as life insurance instruments in the face of life risks. This research aims to analyze the relationship between the interest rate relationship is inversely proportional to the amount of the premium on the pension plan. The method used is to measure several variables, among others FSL (Future Service Liability), PVFSAL (Present Value Future Salary), PR (Pension Rate) and Premiums. Calculation, life annuity uses actuarial assumptions, one of which is the interest rate assumption, if the assumptions used are not in accordance with the actual conditions, then what happens is excessive payments or deficient payments. The interest rate has an influence in the process of calculating the defined benefit pension plan premium. Using the assumption of different interest rates $(11 \%, 12 \%$ and $13 \%)$, it is found that the interest rate relationship is inversely proportional to the amount of the premium. The results of this study are FSL, PVFSAL, PR and Premiums for the interest of $11 \%, 12 \%$ and $13 \%$ (participants aged 25 years) as follows 720,187.97; 554,000,24; 430,570.07 (FSL in Rupiah); 27,155,187.70; 24,922,770,59; 23,002,699.40 (PVFSAL in Rupiah); 2.6521; 2.2229; 1.8718 (PR in\%) and 55,535.38; 46,546.85; 39,196.00 (Premiums in Rupiah)The higher the interest rate, the smaller the pension premium and vice versa.
\end{abstract}

This is an open acces article under the CC-BY license.

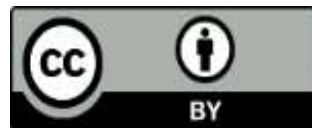

This is an open access article distributed under the Creative Commons 4.0 Attribution License, which permits unrestricted use, distribution, and reproduction in any medium, provided the original work is properly cited. (C2020 by author.

\section{Corresponding Author :}

Khafsah Joebaedi

Department of Mathematics, Faculty of Mathematics and Natural Science (FMIPA) 
Universitas Padjadjaran, Bandung, Indonesia

Email : khafsah.joebaedi@unpad.ac.id

\section{Introduction}

Pension fund funding either in order to meet the requirements or for the purpose of managing financial management will cause the occurrence of wealth which will later be used to pay pension benefits and administrative costs(1-3). In practice, the urgency of the pension program is applied with the precautionary principle because pension funds must also pay attention to wealth for funding. This means that the wealth of the pension fund is calculated to determine the quality of the Pension Fund funding and the existence of solvency obligations and actuary obligations that must be fulfilled in the program. But in reality, there are still not many optimal studies to examine this issue in depth(4-13).

A Pension Fund formed by a person or entity that employs employees, as the founder, to hold a pension program. In a pension program, the amount of pension benefits received by participants at retirement is determined in advance based on a formulation of pension benefits in accordance with the applicable pension fund regulations, then the contribution fee / premium is calculated. To estimate the amount of actuarial liabilities, it is based on applicable actuarial assumptions[14]. Actuarial assumptions are calculations of future changes, which apply to actuarial valuations. So that in each assessment period, adjustments can arise that arise from differences between assumptions and reality, including because changes in the assumptions themselves, referred to as Actuarial Advantages and Disadvantages[15]. Or if the actual situation is not in accordance with the prevailing assumptions, then there is excessive or under-financing (payments that are actuarially unfair)[14].

This paper aims to analyze mathematically the relationship between pension plans implemented by various parties, and their relationship with the pension benefits received later. The analysis will consider the assumptions about the premiums issued by participants by mathematical modeling and the value of the benefits to be obtained later for participants of the pension fund program. With this study, it will be seen how the relevance of the pension fund premiums and other actuarial obligations related to the pension fund program so that the relationship between the pension fund program and the pension premiums can be identified as well as the benefits obtained by participants in the future.

\section{Experimental Section}

This research approach uses a quantitative method, which uses a framework of thought and theory to be developed into a data analysis, where this approach is based more on data calculated for a strong quantitative estimation. In this research, the approach was made in the form of mathematical assumptions and interpreted in groups based on the aims, benefits and time of the study. This type of research based on its purpose is an explanatory research because this study presents an overview and exposes it in research, and is carried out to find an explanation of why an event or event occurred. The final result of this research is a description of the causal relationship.

Data collection in this research is to reduce mathematical equations and conduct a literature study based on articles, scientific papers and journals related to interest rates and retirement planning. The problems to be discussed are Changes in actuarial assumptions at the interest rate and the impact of actuarial assumption changes in the pension program premium calculation process, as well as knowing the benefits or losses for participants due to changes in these assumptions. The assumptions used are $11 \%, 12 \%$ and $13 \%$ interest. The age of the participants used was 25 years. Measurement variables in this research are others FSL (Future Service Liability), PVFSAL (Present Value Future Salary), PR (Pension Rate) and Premiums. 
3. Results and Discussion

3.1 Calculation of the Pension Program

Pension fund calculation requires supporting data from pension program participants, among others [5]; current age (at valuation), age when starting work and current monthly salary. These three variables will be the determining factor for calculating how the FSL and PSVSAL values will be measured. In this measurement the following formula is used;

\subsubsection{Calculating FSL (Future Service Liability)}

Future Service Liability use equations

Amount of FSL $=$ PPNC $_{\mathrm{FSL}}+\mathbf{P P J D P}_{\mathrm{FSL}}$ where:

$$
\begin{aligned}
& \mathrm{PPNC}_{\mathrm{FSL}}=2,5 \% \cdot P h D P . m k d .(a \ell)_{x}^{r a, i a} \\
& \operatorname{PPJDP}_{\mathrm{FSL}}=60 \% \cdot 2,5 \% \cdot P h D P . m k d(x) .{ }^{z, z r}(a \ell)_{x}^{d(w a)} \\
& (a \ell)_{x}^{r a, i a}=\left({ }^{z} \bar{M}_{x}^{r a} /{ }_{s} D_{x}\right)+\left({ }^{z} \bar{M}_{x}^{i a} /{ }_{s} D_{x}\right) \\
& { }^{z, z r}(a \ell)_{x}^{d(w a)}=\left({ }^{z} \bar{M}_{x}^{d(w a)} /{ }_{s} D_{x}\right)+\left({ }^{z r} \bar{M}_{x}^{d(w a)} /{ }_{s} D_{x}\right)
\end{aligned}
$$

\subsubsection{Calculating PVFSAL (Present Value Future Salary)}

Present Value Future Salary use equations

$$
(P V F S A L)_{x}=\frac{P h D P}{{ }^{s} D_{x}}{ }^{s} \bar{N}_{x}
$$

To calculate the Normal Fee in the form of a percentage $(P R)$, that is

$$
P R=\frac{F S L}{P V F S A L} \times 100 \%
$$

\begin{tabular}{|c|c|c|c|c|}
\hline $\begin{array}{c}\text { Interest Rate } \\
\text { (i) }\end{array}$ & $\begin{array}{c}\text { FSL amount } \\
(\mathrm{Rp})\end{array}$ & $\begin{array}{c}P V F S A L \text { amount } \\
(\mathrm{Rp})\end{array}$ & $P R(\%)$ & $\begin{array}{c}\text { Normal Fee } \\
\text { (Rp) }\end{array}$ \\
\hline $11 \%$ & 27.333.109,19 & $828.037 .630,13$ & 3,3 & $2.896 .844,51$ \\
\hline $12 \%$ & $22.771 .063,92$ & 777.461.394,73 & 2,9 & $2.570 .340,81$ \\
\hline $13 \%$ & $19.176 .892,93$ & $732.771 .326,93$ & 2,6 & $2.296 .656,26$ \\
\hline
\end{tabular}

Normal contributions in rupiah have a formula: Amount $\mathrm{PhDP} \times P R$

Measurements made with the formula above produce FSL, PVFSAL, PR and premium with i $=12 \%$ and $\mathrm{i}=13 \%$ are presented in table 1

Table 1 Results of the calculation of the FSL amount, PVFSAL amount, and premiums with $i=11 \%, i=12 \%$, dan $i=13 \%$

\subsection{Calculation of Pension Fund for a person with $x$-years old}

The pension fund calculation is illustrated in a retired participant at 25 years with changes in assumptions at the interest rate of $11 \%, 12 \%$, and $13 \%$ as follows: 
FSL calculations of 25 years are as follows:

$$
\begin{aligned}
F S L= & 2,5 \% \cdot P h D P . m k d(x) \cdot(a \ell)_{x}^{r a, i a}+60 \% \cdot 2,5 \% \cdot \operatorname{PhDP} \cdot m k d(x) .{ }^{z, z r}(a \ell)_{x}^{d(w a)} \\
& \text { Will be calculated }(a \ell)_{x}^{r a, i a}=\left({ }^{z} \bar{M}_{x}^{r a} /{ }_{s} D_{x}\right)+\left({ }^{z} \bar{M}_{x}^{i a} /{ }_{s} D_{x}\right)
\end{aligned}
$$

for normal retirement participants with $x=25, i=11 \%$ obtained

$$
{ }^{z} \bar{M}_{25}^{r a} /{ }_{s} D_{25}=\frac{\left({ }^{z} M_{25}^{r a}+{ }^{z} M_{25+1}^{r a}\right) 1 / 2}{l_{25} \cdot v^{25+1 / 2} \cdot s_{25}}
$$

for pensioners with disabilities with $\mathrm{x}=25, i=11 \%$ obtained

$$
{ }^{z} \bar{M}_{25}^{i a} /{ }_{s} D_{25}=\frac{\left({ }^{z} M_{25}^{i a}+{ }^{z} M_{25+1}^{i a}\right) 1 / 2}{l_{25} \cdot v^{25+1 / 2} \cdot s_{25}}
$$

Next calculation: $\quad{ }^{z, z r}(a \ell)_{x}^{d(w a)}=\left({ }^{z} \bar{M}_{x}^{d(w a)} /{ }_{s} D_{x}\right)+\left({ }^{z r} \bar{M}_{x}^{d(w a)} /{ }_{s} D_{x}\right)$

for widow / widower retirement participants because they died with $\mathrm{x}=25, i=11 \%$

$$
{ }^{z} \bar{M}_{25}^{d(w a)} /{ }_{s} D_{25}=\frac{\left({ }^{z} M_{25}^{d(w a)}+{ }^{z} M_{25+1}^{d(w a)}\right) 1 / 2}{l_{25} \cdot v^{25+1 / 2} \cdot s_{25}}
$$

for retired widow / widower retirement participants with $\mathrm{x}=25, i=11 \%$

$$
{ }^{r r} \bar{M}_{25}^{d(w a)} /{ }_{s} D_{25}=\frac{\left({ }^{z r} M_{25}^{d(w a)}+{ }^{z r} M_{25+1}^{d(w a)}\right) 1 / 2}{l_{25} \cdot v^{25+1 / 2} \cdot s_{25}}
$$

PVFSAL calculation of 25 years are as follows:

$$
(P V F S A L)_{25}=\frac{P h D P}{{ }^{s} D_{25}}{ }^{s} \bar{N}_{25}
$$

\section{Calculation of pension contributions and benefits}

Contributions to participants of defined benefit pension plans at 25 years are:

Annual contribution $=\frac{F S L}{P V F S A L} \times 100 \% \times P h D P$

Benefits per year $=12^{\times} \mathrm{PhDP}^{\times}$work period $\times 2,5 \%$

With the same formulation, it is also calculated for $i=12 \%$ and $i=13 \%$ with the results presented in the table 2

Table 2 The results of FSL, PVFSAL and Premium participants retirement aged 25 years with $\mathrm{i}=11 \%, i=12 \%$, and $i=13 \%$

\begin{tabular}{cccc}
\hline Interest Rate (i) & $\mathbf{0 , 1 1}$ & $\mathbf{0 , 1 2}$ & $\mathbf{0 , 1 3}$ \\
\hline FSL (Rp) & $720.187,97$ & $554.000,24$ & $430.570,07$ \\
PVFSAL (Rp) & $27.155 .187,70$ & $24.922 .770,59$ & $23.002 .699,40$ \\
PR (\%) & 2,6521 & 2,2229 & 1,8718 \\
Premiums (Rp) & $55.535,38$ & $46.546,85$ & $39.196,00$ \\
Benefits per year (Rp) & $18.846 .000,00$ & $18.846 .000,00$ & $18.846 .000,00$ \\
\hline
\end{tabular}


From the above calculation it can be seen that the pension program with attractive interest variations, $11 \%, 12 \%$ and $13 \%$, gives a difference in the benefits obtained by participants. At the $11 \%$ interest offered, the interest charged to the participants reached $2.6 \%$ and the premium charged was IDR 55,535.38 with greater liability. Liability charged to participants reaches Rp. 720,187.97 and the value of assets to come to $\operatorname{Rp} 27,155,187.70$ (the highest compared to $i 12 \%$ and $i 13 \%$ ).

In the higher interest rates, which are $12 \%$ and $13 \%$, it turns out that the pension interest is also low, which is $2.2229 \%$ and $1.8718 \%$ for $\mathrm{i}=12 \%$ and $\mathrm{i}=13 \%$. This decrease is also in line with the decline in the value of FSL and PVFSAL, namely Rp. 24,922,770.59 (PVFSAL for $\mathrm{i}=12 \%$ ) and Rp. 23,002,699.40 (PVFSAL for $i=13 \%$ ), while for the FSL respectively at $i=12 \%$ is Rp.554,000.24 and at $\mathrm{i}=13 \%$ is Rp. 430,570.07. The value obtained from this measurement can reflect the benefits obtained by participants in the pension plan based on the interest given.

Based on the results of this study it appears that there is a tendency for an increase in the value of the benefits obtained by participants if the interest offered is small in the same time frame. Pension fund participants should choose a program that has a small pension fund interest rate, in order to get more benefits and benefits. Conversely, the higher the interest of the pension fund program offered, the smaller the benefits obtained by participants of the pension fund program[16].

\section{Conclusion}

After completing the authors get several conclusions, including In calculating the pension plan, the assumption factors used greatly influence the results of the calculation. From the results of the discussion it can be shown that the impact of changes in interest rate assumptions is very influential in the valuation of the retirement program so that the relationship between changes in interest rate assumptions is inversely proportional to the amount of premiums generated. The higher the interest rate will cause the premium to decrease and vice versa. With higher interest rates, the participants of the Pension Program will benefit because with the same pension benefits, the higher the interest rate, the lower the premiums issued by participants and vice versa. Of the three offered interest variables $(11 \%, 12 \%$ and $13 \%)$, then to get more benefits, the interest on the pension program is $11 \%$.

\section{Acknowledgments}

The researcher would like to thank for the financial assistance provided by Padjadjaran University so that the research went well.

\section{References}

[1] Blomquist NS, Wijkander H. Fertility waves, aggregate savings and the rate of interest. Journal of population economics. 1994;7(1):27-48.

[2] Bourcier De Carbon P. [Fluctuations in relative income and the baby boom in the United States]. Population et avenir. 1997(635):2-6.

[3] Brinner RE. U.S. outlook issues: putting America's house in order. Academic medicine : journal of the Association of American Medical Colleges. 1989;64(3):131-4.

[4] Manns B, McKenzie SQ, Au F, Gignac PM, Geller LI, Canadians Seeking S, et al. The Financial Impact of Advanced Kidney Disease on Canada Pension Plan and Private Disability Insurance Costs. Canadian journal of kidney health and disease. 2017;4:2054358117703986.

[5] Ediev DM. Why increasing longevity may favour a PAYG pension system over a funded system. Population studies. 2014;68(1):95-110.

[6] Liu T, Flothmann EJ. [The new aging society: demographic transition and its effects on oldage insurance and care of the elderly in China]. Zeitschrift fur Gerontologie und Geriatrie. 2013;46(5):465-75. 
[7] Hungerford T, Rassette M, Iams H, Koenig M. Trends in the economic status of the elderly, 1976-2000. Social security bulletin. 2001;64(3):12-22.

[8] Johansson PO. Properties of actuarially fair and pay-as-you-go health insurance schemes for the elderly. An OLG model approach. Journal of health economics. 2000;19(4):477-98.

[9] Kolmar M. Intergenerational redistribution in a small open economy with endogenous fertility. Journal of population economics. 1997;10(3):335-56.

[10] Mathisen K. [Pension taxation. New settlement does not ensure a real interest rate of 3.5]. Sygeplejersken. 1983;83(16):18-9.

[11] Poole CJ. Retirement on grounds of ill health: cross sectional survey in six organisations in United Kingdom. Bmj. 1997;314(7085):929-32.

[12] Prinz A. Endogenous fertility, altruistic behavior across generations, and social security systems. Journal of population economics. 1990;3(3):179-92.

[13] Zimmermann M, Glaser-Moller N, Deck R, Raspe H. [Subjective need for rehabilitation, intention to apply and application for medical rehabilitation--results of a survey of federal insurance office]. Die Rehabilitation. 1999;38 Suppl 2:S122-7.

[14] Larson, Robert. E. and Gaumnitz, Erwin. A. 1962. Life Insurance Mathematics. USA: John Willey \& Sons, inc

[15] Winklevoss, Howard.E. 1976. Pension Mathematics with Numerical Illustration. USA: Published by Pension Research Council and University of Pennsylvania Press.

[16] Anderson, Arthur.W. 1985. Pension Mathematics for Actuaries. Massachusetts Published in Needhan: The Windsor Press Inc. 